mgr inż. Iwona CŁAPA ${ }^{1}$

prof. dr hab. inż. Marek DZIUBIŃSKI ${ }^{1}$

Przyjety/Accepted/Принята: 25.08.2013;

Zrecenzowany/Reviewed/Рецензирована: 25.07.2014;

Opublikowany/Published/Опубликована: 30.09.2014;

\title{
ZACHOWANIE LUDZI JAKO JEDEN Z CZYNNIKÓW DETERMINUJĄCYCH PRZEBIEG PROCESU EWAKUACJI ${ }^{2}$
}

\author{
Human behaviour as one of the factors determining the course \\ of the evacuation process
}

\author{
Поведение людей как один из факторов, определяющий \\ ход процесса эвакуации
}

\begin{abstract}
Abstrakt
Cel: Celem niniejszego artykułu jest przedstawienie zachowania wybranej grupy ludzi w średnim wieku podczas ewakuacji z reprezentatywnego budynku użyteczności publicznej.

Wprowadzenie: W artykule omówiono czynniki wpływające na przemieszczanie się thumu podczas zdarzenia ekstremalnego, którym może być alarm pożarowy lub inne zagrożenie takie jak na przykład alarm bombowy w budynku. Wyjaśniono definicję thumu, a także ukazano możliwe zachowania się ludzi podczas ewakuacji reprezentatywnej grupy ludzi w średnim wieku. Dane literaturowe, a zwłaszcza modele obliczeniowe w głównej mierze wykorzystywane są do określania maksymalnego czasu potrzebnego do bezpiecznego opuszczenia obiektu tj. wyjścia na zewnątrz budynku lub do wyznaczonego bezpiecznego miejsca lub sąsiedniej strefy pożarowej. Metody te, z uwagi na wprowadzone uproszczenia, są łatwe i szybkie w kalkulacjach, jednak w większości przypadków nie uwzględniają wpływu zachowań użytkowników budynku na czas ewakuacji. Po ogłoszeniu alarmu pożarowego zaobserwować można różne zachowania ludzi takie jak kończenie rozpoczętych czynności, pakowanie i zabieranie rzeczy osobistych, szukanie członków rodziny, próby gaszenia pożaru, przyglądanie się, co się dzieje, próby kradzieży przy wykorzystaniu panującego zamieszania i wiele innych czynności, które wydłużają czas ewakuacji, a tym samym mają negatywny wpływ na poziom bezpieczeństwa ludzi.

Wnioski: Stosowane w modelach obliczeniowych uproszczenia i brak odniesienia się do przewidywalnych zachowań podczas ewakuacji powodują, że otrzymane wyniki mogą odbiegać w znacznym stopniu od czasów rzeczywistych potrzebnych na opuszczenie budynku.

Znaczenie dla praktyki: Przedstawiony eksperyment wykonany w jednym z łódzkich budynków wysokościowych przedstawia najczęściej obserwowane zachowania ludzi podczas próbnych ewakuacji. Eksperyment nie obejmował badania zachowań oraz czasu ewakuacji osób niepełnosprawnych. Został on porównany z wykonaną symulacją komputerową przy użyciu programu Pathfinder i jest obecnie najczęściej używanym modelem obliczeniowym opisanym w literaturze przedmiotu, dzięki czemu otrzymano pogląd na szacowane czasy ewakuacji przy użyciu różnych narzędzi inżynierii bezpieczeństwa pożarowego. Eksperyment miał również na celu sprawdzenie występowania modelu koncepcyjnego wyróżniającego poszczególne fazy: postrzegania, interpretacji, podejmowania decyzji i akcji w trakcie ewakuacji z budynku.
\end{abstract}

Słowa kluczowe: zachowanie ludzi, ewakuacja, tłum, zachowanie tłumu, eksperyment Typ artykułu: studium przypadku

\begin{abstract}
Aim: The purpose of this article is to show how a representative middle-aged group of people tend to behave during the implementation of an evacuation procedure in a given public building.

Introduction: This article describes factors which, influence people's mobility in extreme circumstances, such as: the sounding of a fire alarm or bomb alert in a building. The article defines the term "crowd" but also illustrates potential behaviour of middle-aged group of evacuees. Data, specifically calculation models are, in the main, employed to determine the maximum lead time necessary for safe evacuation of a building - exit a building to a safe location or an adjacent fire free zone. Calculations, because of simplification,
\end{abstract}

\footnotetext{
${ }^{1}$ Politechnika Łódzka, ul. Wólczańska 175, 90-924 Łódź; ivona2005@wp.pl / Lodz University of Technology, Poland;

${ }^{2}$ Wkład merytoryczny w powstanie artykułu / Percentage contribution: I. Cłapa - 70\%, M. Dziubiński - 30\%;
} 
are quick and straightforward but, in the main, ignore human behavioural aspects during evacuation. After sounding of a fire alarm one can observe a range of reactions such as: completion of work in progress, collection and packing of personal items, a search for family members, attempts to extinguish fires, people gaping at what is going on, others exploiting the confusion with theft attempts and other happenings which, extend the evacuation lead time and negatively impact on the safety of people.

Conclusion: Simplification of calculation models and lack of due regard to human behavioural aspects, during an evacuation, may contribute to a significant divergence from realistic time requirements necessary to vacate a building.

Practical impact: The described experiment, conducted in a high rise building, in the city of Łódź, illustrates most frequently observed behaviour of people during an evacuation practice. The experiment did not incorporate an evaluation of behaviour or duration of an evacuation involving disabled people. The experiment outcome was compared with Pathfinder, a computer simulation programme and currently most frequently used calculation model described in this article. This facilitated a deeper insight into calculated evacuation lead times using a range of engineering tools harnessed in fire safety. The experiment also allowed for the verification of individual phases of the conceptual simulation model, highlighting distinctive phases such as: perception, interpretation, decision making, and direct action during an evacuation.

Keywords: human behavior, evacuation, crowd, crowd behaviour, experiment Type of article: case study

\section{Аннотация}

Цель: Целью данной статьи является описание поведения выбранной группы людей среднего возраста во время эвакуации из представленного общественного здания.

Введение: В статье рассмотрены факторы, влияющие на движение толпы людей во время экстремальной ситуации: пожарной тревоги или другой угрозы, например, угрозы заминирования здания. Подано объяснение термина „толпа”, а также представлены возможные варианты поведения выбранной группы людей среднего возраста во время эвакуации. Литературные данные, а именно, вычислительные модели, в главной мере, используются для определения необходимого времени для безопасной эвакуации из объекта т.е. выхода наружу здания либо прибытия в назначенное безопасное место или в соседнюю пожарную зону. Эти методы, в связи с введёнными упрощениями, простые и быстрые в подсчётах, однако, в большинстве случаев не учитывают влияние поведения людей, находящийся в здании во время эвакуации. После объявления пожарной тревоги наблюдается разные поведения людей, такие как, например, завершение начатых действий, пакование и сбор личных вещей, поиск членов семьи, попытки тушения пожара, наблюдение за происходящим, попытки кражи используя ситуацию общей паники и беспорядка и многие другие, которые увеличивают время эвакуации, тем самым, отрицательно влияя на уровень безопасности людей.

Выводы: Используемые в вычислительных моделях упрощения и отсутствие учёта предсказуемого поведения людей во время эвакуации, могут привести к тому, что полученные результаты будут существенно отличаться от реального времени необходимого, чтобы покинуть здание.

Значение для практики: Представленный эксперимент, проведенный в одном из многоэтажных зданий г. Лодзи, показывает наиболее распространенное поведение людей, которое можно наблюдать во время пробных эвакуаций. Во время эксперимента не исследовали поведение и время эвакуации инвалидов. Эксперимент был сравнён с проведённой компьютерной симуляцией при использовании программы Pathfinder и с наиболее популярной вычислительной моделью, описанной в предметной литературе. Благодаря этому была получена информация о приблизительной длительности эвакуации при использовании разных инструментов инженерии пожарной безопасности. Эксперимент также был проведён для проверки отдельных фаз концептуальной модели: восприятия, интерпретации, принятия решений и действий во время эвакуации из здания.

Ключевые слова: поведение людей, эвакуация, толпа людей, поведение толпы, эксперимент

Вид статьи: тематическое исследование

\section{Zarys historyczny}

Zainteresowanie problemem ewakuacji rozpoczęło się po serii tragicznych pożarów, w wyniku których zginęła bardzo duża liczba osób. Największym i najtragiczniejszym pożarem w historii ludzkości był pożar w teatrze Iroquois w Chicago w 1903 r., gdzie zginęły 602 osoby. Drugim co do liczby ofiar był pożar w klubie nocnym Cocoanut Grove w Bostonie w dniu 28 listopada 1942 r. Zginęły wówczas 492 osoby, a rannych zostało kilka tysięcy [1]. W 2006 r. w Stanach Zjednoczonych [2] w pożarach zostało rannych ponad 14000 osób, a śmierć poniosło ponad 2700 osób. Analiza urazów i zgonów spowodowanych pożarami wykazała, że ponad dwie trzecie rannych i ponad połowa ofiar śmiertelnych była w stanie ewakuować się z budynku. Jednak ludzie ci wykonywali czynności, które spowodowały opóźnienia w rozpoczęciu ewakuacji np. kończyli rozpoczęte czynności, gasili ogień, próbowali ratować innych z budynku [3].
W tym czasie pożar spowodował, że parametry krytyczne na drogach ewakuacyjnych zostały przekroczone, co w konsekwencji spowodowało śmierć lub poważne obrażenia, w następstwie których zginęli.

Po tych zdarzeniach zaczęto się zastanawiać, co wpływa na zachowanie ludzi podczas pożaru oraz w jaki sposób zapewnić ludziom bezpieczną ewakuację. Zwrócono szczególną uwagę na potrzebę zapewnienia bezpieczeństwa przez wymagany czas, a także na odpowiednie środki gwarantujące bezpieczną ewakuację wszystkich osób przebywających w budynku.

Zaczęto poddawać analizie obowiązujące dotychczas procedury i przyjęte scenariusze pożarowe. Zaobserwowano [4], że zamiast modelowania i przewidywania zachowań użytkowników, niektóre modele ewakuacji posiadają z góry określone założenia i uproszczenia dotyczące zachowań ludzi. Często są one nierealne i mogą powodować otrzymanie niedokładnych wyników. Jednym 
z podstawowych błędów może być założenie natychmiastowej ewakuacji po usłyszeniu alarmu pożarowego lub wykryciu pożaru, co może skutkować znacznym skróceniem obliczeniowego czasu ewakuacji, a w konsekwencji prowadzić do nieświadomego projektowania niebezpiecznych warunków np. niewystarczającej liczby wyjść ewakuacyjnych, opracowania niewłaściwych procedur organizacyjnych.

Sytuacja może być również odwrotna. Niewłaściwe założenia mogą prowadzić do przeszacowania wyników i wyznaczenia znacznie dłuższego czasu ewakuacji. Zaprojektowane na takiej podstawie budynki lub opracowane procedury mogą niepotrzebnie podnieść koszty inwestycji. Dlatego tak ważne jest, aby właściwie określić model zachowań ludzkich podczas ewakuacji i prawidłowo wyznaczyć czas niezbędny do ewakuacji.

\section{Proces ewakuacji ludzi z budynków}

We wczesnej fazie rozwoju pożaru (ryc. 1) ludzie znajdujący się w budynku lub pomieszczeniu zagrożonym pożarem, zmuszeni do podjęcia czynności ewakuacyjnych mogą polegać na:

- indywidualnych umiejętnościach oraz własnej wiedzy o zjawisku pożaru i jego rozprzestrzenianiu,

- na możliwości uratowania ich przez inne osoby znajdujące się w ich najbliższym otoczeniu.

Udział służb ratowniczych w procesie ewakuacji zapewniony będzie jedynie po ich przybyciu na miejsce, co przy uwzględnieniu czasu zaalarmowania i dojazdu może nastąpić w fazie flashover pożaru, a co za tym idzie, parametry krytyczne na drogach ewakuacyjnych mogą być już przekroczone. Dlatego też zachowanie ludzi w zagrożonym obiekcie podczas pierwszej fazy rozwoju pożaru jest niezwykle istotnym czynnikiem, mającym zasadniczy wpływ na sprawność przeprowadzenia ewakuacji.

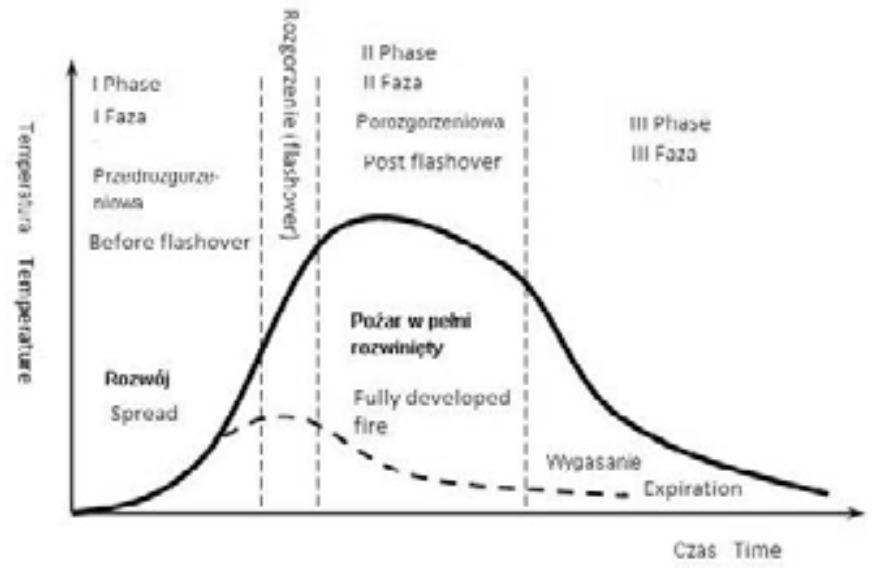

Ryc. 1. Krzywa przedstawiająca przebieg pożaru pomieszczenia wyrażona średnią temperaturą gazu w funkcji czasu. Linia przerywana przedstawia zużycie paliwa przed momentem wystąpienia rozgorzenia [5]

Fig. 1. A curve showing the course of the fire space expressed by the mean gas temperature as a function of time. The dotted line shows the consumption prior to the time of flashover [5]

\section{Zachowanie ludzi podczas ewakuacji}

Na początku XX wieku prowadzono szereg prac badawczych w zakresie poprawności, efektywności oraz identyfikacji czynników zewnętrznych mających wpływ na proces ewakuacji ludzi z budynków, ze szczególnym uwzględnieniem prędkości przemieszczania się ludzi oraz wzajemnych sił oddziaływania na siebie podczas ewakuacji w korytarzach, na klatkach schodowych oraz przejściach ewakuacyjnych. Zbudowano wówczas kilka baz danych $[5,6,7]$ dotyczących takich parametrów ewakuacji jak prędkości przemieszczania się oraz widoczności $\mathrm{w}$ dymie. Badania przeprowadzone w tamtym okresie do dnia dzisiejszego stanowią fundamentalną wiedzę w zakresie określania bezpiecznych warunków ewakuacji, a także nierzadko są wykorzystywane w przepisach i normach technicznych na całym świecie $[8,9]$.

Jako jedni z pierwszych badaniem zjawiska zachowania się ludzi zajmowali się między innymi w latach pięćdziesiątych XX wieku Hankin i Wright [10], w latach sześćdziesiątych Hoel [11] oraz Older [12], w latach siedemdziesiątych O'Flaherty i Parkinson [13]. Wszystkie uzyskane przez nich wyniki oparte były na bezpośredniej obserwacji dokonanej za pomocą fotograficznej analizy poklatkowej (ang. time-lapse films). Badania polegały przede wszystkim na obserwacji zachowań, tworzenia się strumieni ludzi i kształtowania się ich przepływu.

W literaturze przedmiotu znaleźć można opisy różnych modeli zachowania się ludzi podczas ewakuacji [14] m.in:

- modele kolejkowania (ang. queueing models) [15, 16],

- modele macierzy przejścia (ang. transistion matrix models) [17],

- modele stochastyczne [12].

W latach siedemdziesiątych Henderson [18, 19, 20] zaproponowal, aby zachowanie thumu potraktować jak zachowanie cząstek gazu lub płynu. Przy takim podejściu należało odnieść się do poszczególnych zależności pomiędzy tymi cząsteczkami, wśród których należy wymienić unikanie przeszkód, a także zmniejszenie prędkości poruszania się, przez co nie do końca spełnione są klasyczne zasady zachowania energii i pędu. W swoich założeniach wykorzystywał on równania Naviera-Stokesa, czyli zestaw równań w postaci równań ciagłości opisujących zasadę zachowania masy i pędu dla poruszającego się płynu, według których zmiany pędu elementu płynu zależą jedynie od zewnętrznego ciśnienia i wewnętrznych sił lepkości w płynie opisujących przepływ laminarny cieczy newtonowskiej (kolejne warstwy płynu nie ulegają mieszaniu). Przepływ zachodzi przy małych prędkościach, gdy liczba Reynoldsa nie przekracza tzw. wartości krytycznej.

\section{Czym jest thum i jak się zachowuje?}

W zależności od tego, czy jednostka jest odosobniona, czy znajduje się w grupie, jej zachowanie może być różne. W przypadku gdy człowiek jest sam i zauważy zagrożenie, $\mathrm{z}$ reguły będzie postępować instynktownie, a więc najczęściej po przerwaniu rozpoczętych czynności przemieszczał się będzie w kierunku miejsca bezpiecznego. Sytuacja komplikuje się w przypadku przebywania w grupie. Aby lepiej poznać zachowania ludzi, należałoby dowiedzieć się, czym jest tłum i jakimi rządzi się prawami. 
Zgodnie ze wskazaniami Encyklopedii PWN [21] tłum to zgromadzenie wielu ludzi skupionych blisko siebie, związanych przelotnie silną więzią psychiczną, przejawiającą się we wspólnym spontanicznym zachowaniu - narzucone przez emocje działania nie są oceniane krytycznie. W tłumie dochodzi często do naśladownictwa i (chwilowego) wyzbywania się indywidualizmu. Często też uczestnicy tłumu czują się silniejsi i tracą zdolność obiektywnej oceny sytuacji.

Najpopularniejszy podział tłumu zaprezentowany został przez Blumera w 1951 r. w „Collective Behavior” [22, 23]. Autor przedstawił w nim następujące rodzaje tłumu:

- tlum przypadkowy - charakteryzuje się słabymi oddziaływaniami pomiędzy jego uczestnikami, a nawet ich brakiem. Powstaje na skutek określonego wydarzenia. Przykładem takiego tłumu są osoby przyglądające się wypadkom, egzekucjom itp.;

- thum konwencjonalny - czyli zbiór osób zgromadzonych w konkretnym celu, który osiągany jest przez każdą osobę z tłumu odrębnie. Przykładem takiego thumu są widzowie na koncertach, w kinie, pasażerowie na przystanku. Tłum taki bardzo często nazywany jest publicznością;

- thum ekspresyjny - czyli taki, w którym szczególną rolę odgrywa określony ładunek emocjonalny, a w konsekwencji na nim oparte są dalsze zachowania się tłumu. Przykładem takiego tłumu są uczestnicy zabaw sylwestrowych na rynkach miast, karnawału w Rio czy też Love Parade w Berlinie. Tłum taki może przejawiać zachowania niedopuszczalne, niespotykające się z powszechną akceptacją;

- tlum aktywny - jest nastawiony na działalność niszczycielską, której celem jest rozładowanie emocji i/lub przeciwnika dokonywanie negatywnego oddziaływania. Przykładem takiego tłumu są agresywni kibice na meczach piłkarskich;

- thum protestujący - jest szczególnym przykładem tłumu, który wykazuje cechy tłumu konwencjonalnego (dość dobra organizacja) oraz tłumu aktywnego (działalność destruktywna).

W sytuacji zagrożenia powyższy podział przestaje jednak obowiązywać, ponieważ cel lub motywy zgromadzenia tłumu przestają być ważne, a na pierwsze miejsce wysuwa się zazwyczaj potrzeba jak najszybszego opuszczenia zagrożonego miejsca oraz dbałość o własne życie, które staje się wartością nadrzędną. W takich przypadkach bardzo często dochodzi do tragicznych obrażeń, a nawet śmierci poprzez stratowanie osób przez innych ewakuujących się ludzi.

Kolejną próbę kwalifikacji tłumu podjął Blumer [22], a następnie rozwinął ją Park [24]. Wprowadzili oni pojęcie „zachowania zbiorowego" (ang. collective behavior), które opisuje działanie pośrednie pomiędzy zachowaniem konformistycznym (zgodnym z normami) a zachowaniem odstępującym od norm. Zachowanie zbiorowe jako trzecia forma działania tłumu zachodzi, gdy normy są sprzeczne ze sobą lub gdy ich brakuje. Oznacza to, że duża liczba wzajemnie obcych sobie ludzi, którzy $\mathrm{w}$ tym samym czasie znaleźli się w tym samym miejscu (np. na koncercie), w wyniku nagłej zmiany sytuacji (np. powstania pożaru), może przekształcić się w „masę”. Pojęcie „masa” wg Le Bona cechuje się anonimowością jednostki, określoną emocjonalnością, obniżeniem poziomu inteligencji oraz odpowiedzialności osobistej:

„Zatem każdą jednostkę w thumie cechuje: zanik świadomości swego »ja«, przewaga czynników nieświadomych, utrata autonomii w kierowaniu myślami i uczuciami pod wpływem sugestii i przeniesienia, a nadto dążenie do jak najszybszego urzeczywistnienia sugerowanych idei. Jednostka przestaje być sobą, staje się automatem, którym kieruje wola narzucona, nigdy zaś własna" [25].

Biorąc pod uwagę obserwacje, a także przeprowadzone badania i dostępne materiały źródłowe najczęściej spotykanymi zachowaniami thumu w czasie sytuacji zagrożenia są:

- przyspieszenie kroku, ruchu, co skutkuje zwiększeniem prędkości poruszania,

- odpychanie się, potrącanie, wpadanie na siebie, a więc wzajemne oddziaływanie,

- poruszanie się w sposób chaotyczny, nieprzewidywalny,

- wracanie się po zapomniane rzeczy, szukanie dzieci i członków rodziny,

- tworzenie się zatorów, zwłaszcza na zwężeniach poziomych dróg ewakuacyjnych przy drzwiach,

- ludzie oddziaływają na siebie siłą fizyczną, przepychają się,

- zwolnienie ruchu poprzez osoby poszkodowane, potykające się, przeszkody,

- bezkrytyczne podążanie za innymi.

Wszystkie te zachowania wpływają negatywnie na przebieg ewakuacji, ponieważ powodować mogą powstanie paniki [23], czyli panicznego lęku, trwogi o swoje życie, co wydłużać będzie czas ewakuacji.

\section{Symulacje zachowań użytkowników w czasie ewakuacji}

Zgodnie z obserwacjami [4], oprócz celowego ruchu osób ewakuujących, użytkownicy skłonni są do wykonywania wielu innych czynności, które mogą opóźnić ich przemieszczanie się na zewnątrz budynku lub wyznaczonego bezpiecznego miejsca. Takie działania mogą obejmować zbieranie informacji, przygotowanie się do ewakuacji, zbieranie swoich rzeczy osobistych, pomoc innym, a nawet ich ratowanie, ostrzeganie innych osób w budynku, zmianę kierunku ewakuacji i gaszenie pożaru.

W obecnych modelach ewakuacji [4] skoncentrowano się głównie na celowym ruchu, a nie na symulacji dodatkowych zachowań, które mogą mieć wpływ na opóźnienie przebiegu całego procesu ewakuacji.

Do symulacji zachowania użytkowników w czasie ewakuacji budynku stosuje się głównie dwie metody. Pierwsza to wprowadzenie czasu zwłoki np. określonego czasu, dla osób lub grup ludzi w symulowanym budynku w celu uwzględnienia wszelkich działan, które mogą być wykonywane w czasie ewakuacji (przed i w trakcie jej trwania). Ta metoda wykorzystywana jest przez następujące modele: Simulex [26, 27], EXIT89 [28], GridFlow 
[29]. Stosując tę metodę, pozostawiamy użytkowników w pozycji wyjściowej na określony czas, a następnie rozpoczynamy celowy ruch ewakuacji.

Drugą metodą jest przypisanie konkretnych zachowań, takich jak kolejność działań, do określonego budynku. Przykładowymi programami wykorzystującymi tę metodę są CRISP [30], buildingEXODUS [31, 32]. Ciągłość ruchu może być przerwana przez takie zachowania jak wyszukiwanie informacji, pozostanie na schodach, pomoc innym osobom, powrót do pierwotnego miejsca w celu zabrania rzeczy osobistych. Każde takie działanie posiada przypisany czas określony dla każdego z użytkowników. Obie te metody symulacji zachowania się podczas ewakuacji posiadają znaczne uproszczenia procesów zachodzących w czasie ewakuacji. Zdaniem Eriki Kuligowski [4] w pierwszej metodzie przy przypisywaniu czasu opóźnienia nacisk kładzie się na opóźnienie (a nie na decyzje) działania i interakcji osób znajdujących się $\mathrm{W}$ reakcji z warunkami panującymi wewnątrz budynku. Druga metoda - przypisywanie zachowań do określonego budynku - zaczyna symulować decyzje i działania podejmowane w odpowiedzi na określone warunki w czasie ewakuacji, jednak wszystkie zachowania są definiowane przez użytkownika przed rozpoczęciem symulacji (zamiast przewidywanych przez model), interakcje między innymi użytkownikami są uproszczone lub nie istnieją.

Głównym problemem powyższych metod jest określenie zachowań ludzi przez użytkownika programu, co ważniejsze, to on określa działania, które występują w scenariuszu pożarowym. Nie ma spójności związanej z przypisywaniem zachowań, ponieważ ww. metody opierają się całkowicie na wiedzy użytkownika programu, jednocześnie brak jest jasnych wytycznych, kompleksowego zbioru danych, czy teorii określających, co ludzie robią w czasie ewakuacji budynku.

\section{Model koncepcyjny zachowania ludzi}

Aby zrozumieć proces zachowania i wpływające na nie czynników, zaprezentowany zostanie model koncepcyjny, który rozróżnia cztery fazy zachowań ludzi [4].

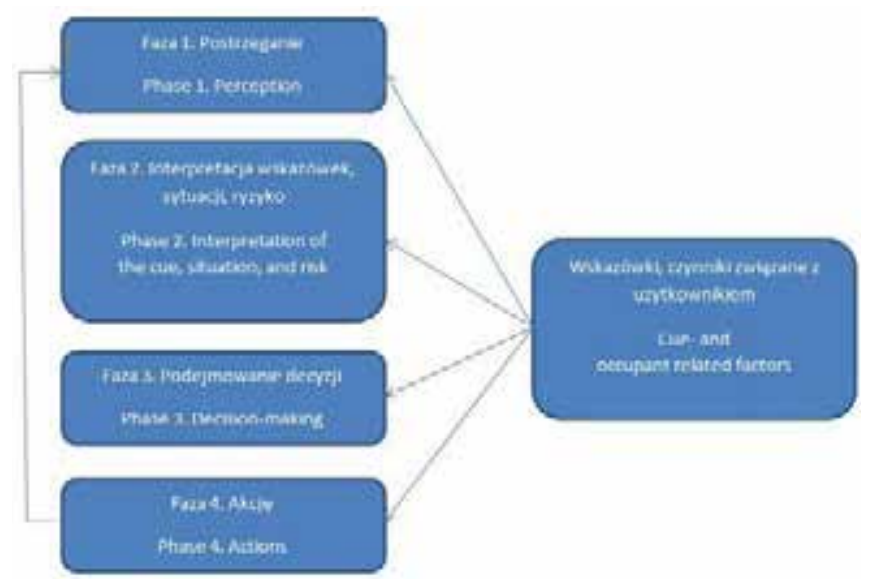

Ryc. 2 Model koncepcyjny zachowań podczas ewakuacji [4] Fig. 2 Conceptual model of behavior during the evacuation [4]

Faza 1 obejmuje zachowania postrzegania, odbierania zewnętrznych sygnałów społecznych w ich otoczeniu [33]. Te sygnały mogą być fizyczne lub mogą mieć cha- rakter społeczny, co oznacza, że wynikają odpowiednio z rzeczywistego środowiska naturalnego lub środowiska społecznego. Przykładami sygnałów fizycznych w pożarze budynku są płomienie, dym, dźwięk tłuczonego szkła, alarmy i ostrzeżenia automatyczne. Te sygnały mogą docierać do użytkowników pojedynczo lub kilka na raz, w zależności od rodzaju i miejsca zdarzenia. Faza postrzegania polega na dotarciu do świadomości użytkownika informacji o tym, że coś się zmieniło w jego otoczeniu [34],[35]. Sygnały docierać mogą do świadomości za pośrednictwem słuchu np. alarm, zapachu np. dym, wzroku np. płomień, smaku np. smak dwutlenku siarki lub chlorowodoru w ustach, czucia np. ciepło.

W fazie interpretacji (faza 2) użytkownicy próbują zinterpretować informacje dostarczone przez bodźce postrzegane w fazie postrzegania [36],[37].

Faza 3 wymaga od osób lub grup ludzi podejmowania decyzji, co dalej robić w oparciu o interpretację sygnałów, sytuacji i zagrożeń. Podejmowanie decyzji w tej fazie jest procesem dwuetapowym, w którym użytkownicy początkowo wyszukują opcje postępowania, a następnie wybierają jedną z nich [4]. Pierwszym krokiem w etapie podejmowania decyzji jest wyszukiwanie opcji, co można zrobić w oparciu o interpretację wydarzenia. Propozycje działań mogą pochodzić od użytkownika lub dowolnego członka grupy [38]. W obliczu niepewności i braku czasu ludzie mogą się spotykać, dzielić interpretacjami oraz określać plan działania. W drugim etapie podejmowania decyzji należy wybrać jedną z opcji wykonania.

W fazie 4 należy wykonywać działania, podjąć akcje, które są ustalane na etapie podejmowania decyzji.

Jeśli nowe informacje/wskazówki zostaną przedstawione zanim akcja zostanie wykonana, użytkownicy będą na bieżąco zmieniać zachowanie. Działania te w zależności od sytuacji mogą obejmować poszukiwania informacji, czekanie, badanie incydentu, ostrzeganie innych, przygotowanie do ewakuacji, pomoc innym, gaszenie pożaru, a także poszukiwanie i ratowanie innych [4].

\section{Eksperyment}

W celu sprawdzenia, czy przedstawiony powyżej model koncepcyjny jest prawdziwy, przeprowadzono obserwacje $\mathrm{w}$ jednym $\mathrm{z}$ lódzkich budynków podczas próbnej ewakuacji.

Badanie oprócz obserwacji zachowań ludzkich miało również na celu pomiar prędkości poruszających się ludzi po pionowych i poziomych drogach ewakuacyjnych. Eksperyment przeprowadzany był w siedemnastokondygnacyjnym budynku biurowym $\mathrm{z}$ dwoma poziomami podziemnymi. Wysokość budynku wynosi ok. $62 \mathrm{~m}$. Powierzchnia wewnętrzna poszczególnych kondygnacji nadziemnych od parteru do 11 piętra wynosi ok. $400 \mathrm{~m}^{2}$, powierzchnia kondygnacji wyższych - ok. $250 \mathrm{~m}^{2}$. Powierzchnia wewnętrzna dwóch połączonych ze sobą kondygnacji podziemnych w sumie wynosi ok. $700 \mathrm{~m}^{2}$. W budynku kondygnacje od 0-11 połączone są dwoma klatkami schodowymi zlokalizowanymi po obu stronach budynku. Klatki te połączone są ze sobą korytarzem, wzdłuż którego znajdują się pokoje biurowe. Od 12 piętra występuje tylko jedna klatka zlokalizowana w central- 
nej części budynku. Klatki boczne są obudowane ścianami i zamknięte drzwiami na wszystkich poziomach. Klatka środkowa jest klatką otwartą.

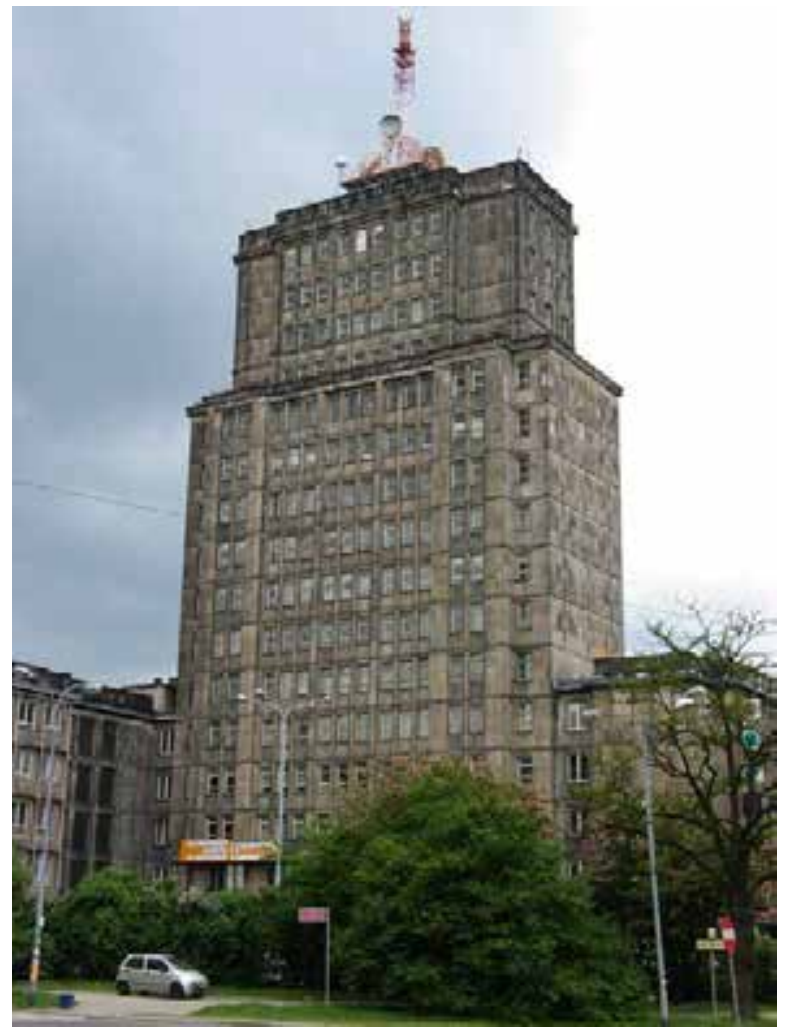

Ryc. 3. Widok budynku z zewnątrz

Fig. 3. View of the building from the outside Źródło: Opracowanie własne.

Source: Own elaboration.

Podczas eksperymentu wykorzystano trzy punkty obserwacyjne umożliwiające rejestrowanie na kamerach wideo przebiegu ewakuacji. Pierwszym punktem obserwacji była pozioma droga ewakuacyjna na 11 piętrze, w miejscu gdzie wzbudzany był system sygnalizacji pożarowej. Drugi punkt obserwacyjny znajdował się w klatce schodowej i miał umożliwić zmierzenie prędkości przemieszczających się ludzi po pionowych drogach ewakuacyjnych, trzeci znajdował się w hallu głównym, gdzie następowało łączenie się strumieni ewakuujących się ludzi. Badana grupa ludzi to osoby aktywne zawodowo w wieku 30-65 lat, mężczyźni i kobiety.

Podczas przebiegu ewakuacji zaobserwowano następujące zachowania:

1. Czynności polegające na dokończeniu rozpoczętych prac, $z$ racji na specyfikę obiektu było to przede wszystkim zakończenie prac rozpoczętych na komputerach, zapisanie stworzonych dokumentów, wyłączanie sprzętu.

2. Wracanie się do pomieszczeń w celu zabrania swoich rzeczy.

3. Zamykanie drzwi na klucz.

4. Czekanie na znajomych, przez co powstawały naturalne przeszkody na drodze ewakuacyjnej.

5. Zmiana kierunku przemieszczania się.

6. Brak zdecydowania, którą klatką schodową się ewakuować.
7. Wpadanie na innych, popychanie ich.

8. Przytrzymywanie się poręczy podczas schodzenia.

9. Zatrzymywanie się podczas ruchu na schodach w celu sprawdzenia, czy znajome osoby idą z tyłu.

10. Przepuszczanie kobiet $w$ drzwiach, na drogach ewakuacyjnych.

11. Dopytywanie się, co się stało, gdzie się pali.

12. Tworzenie się grup ewakuujących się.

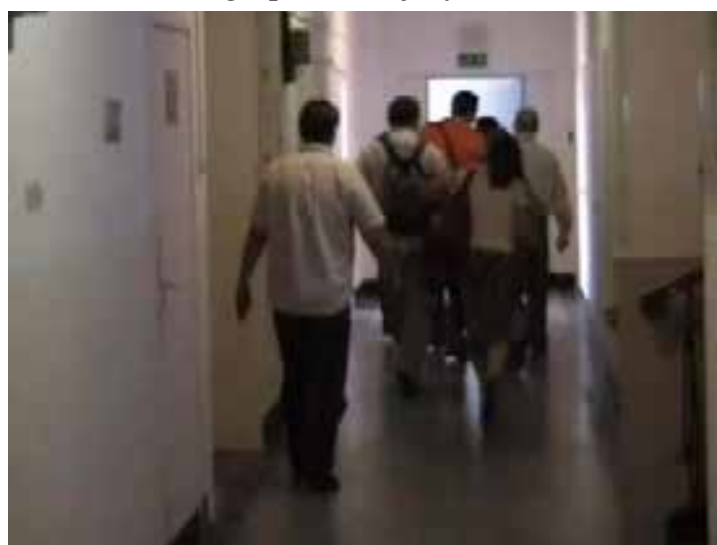

Ryc. 4. Tworzenie się skupisk, grup ewakuujących się ludzi Fig. 4. The formation of clusters, groups of people evacuating Źródło: Opracowanie własne. Source: Own elaboration.

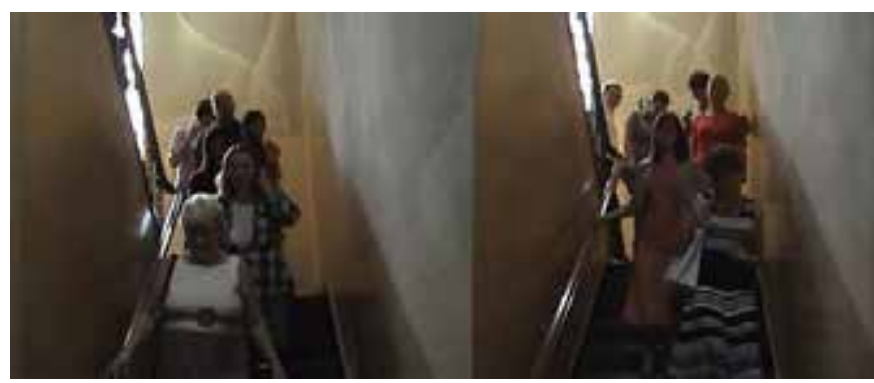

Ryc. 5. Ewakuujący się ludzie na pionowych drogach ewakuacyjnych

Fig. 5. Evacuating people on vertical escape routes Zródło: Opracowanie własne. Source: Own elaboration.

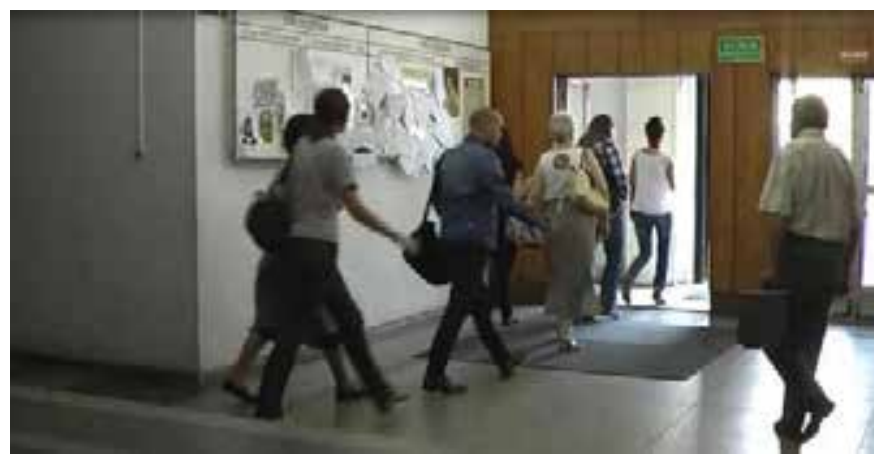

Ryc. 6. Widok łączenia się strumieni ewakuujących się ludzi w hallu głównym

Fig. 6. View connect to streams evacuating people in the main hall

Źródło: Opracowanie własne.

Source: Own elaboration.

$\mathrm{Na}$ podstawie materiału nakręconego przy pomocy kamer wideo określono, że całkowity czas ewakuacji wszystkich ludzi z budynku wyniósł 8 min $56 \mathrm{~s}$. W ewakuacji brało udział 137 osób. Minimalny czas zwłoki wy- 
nosił 1 minutę, natomiast maksymalny wynosił $4 \mathrm{~min}$ 4 sek. Na podstawie przeprowadzonego eksperymentu otrzymano poniższe wartości prędkości przemieszczających się ludzi, które zebrano w tabeli 1.

Tabela 1. Średnie prędkości przemieszczających się osób podczas ewakuacji

Tabela 1.

Average speed of moving people during evacuation

\begin{tabular}{|c|c|c|c|c|}
\hline & \multicolumn{2}{|c|}{$\begin{array}{c}\text { Pozioma droga } \\
\text { ewakuacyjna/ } \\
\text { Horizontal escape route }\end{array}$} & \multicolumn{2}{|c|}{$\begin{array}{c}\text { Pionowa droga } \\
\text { ewakuacyjna/ Vertical } \\
\text { evacuation route }\end{array}$} \\
\hline Płeć/Sex & $\begin{array}{c}\text { Kobieta/ } \\
\text { woman }\end{array}$ & $\begin{array}{c}\text { Mężczyzna/ } \\
\text { man }\end{array}$ & $\begin{array}{c}\text { Kobieta/ } \\
\text { woman }\end{array}$ & $\begin{array}{c}\text { Mężczyzna/ } \\
\text { man }\end{array}$ \\
\hline $\begin{array}{c}\text { Prędkość/ } \\
\text { Speed }\end{array}$ & $\mathbf{1 , 0 2} \mathbf{~ m / s}$ & $\mathbf{1 , 2 1} \mathbf{~ m / s}$ & $\mathbf{0 , 6 0 ~ m / s}$ & $\mathbf{0 , 6 5} \mathbf{~ m / s}$ \\
\hline \multicolumn{4}{|c|}{$\begin{array}{c}\text { Źródło: Opracowanie własne. } \\
\text { Source: Own elaboration. }\end{array}$}
\end{tabular}

Należy zaznaczyć, że są to prędkości zbliżone do danych literaturowych [39]. Przedstawione wyniki obserwacji znalazły swoje odzwierciedlenie również w innych prowadzonych eksperymentach w budynkach użyteczności publicznej podczas próbnych ewakuacji. Przedstawiony eksperyment został wybrany jako reprezentatywny.

\subsection{Otrzymane wyniki przy wykorzystaniu programu do symulacji komputerowej Pathfinder}

Do celów porównania rzeczywistych wyników pomiaru czasu ewakuacji z otrzymywanymi wynikami symulacji komputerowych wykorzystano program Pathfinder [40]. Zawiera on zestaw niezbędnych narzędzi do przeprowadzenia analizy czasów ewakuacji. Definiowalne cechy ludzi znajdujących się w budynku pozwalają na obliczenie granic czasu ewakuacji. Pathfinder jest programem, w którym zdefiniowany osobnik posiada szereg indywidualnych cech, które mogą wpływać na jego ruchy i decyzje podczas samej symulacji niezależnie od innych jednostek [40].

Pathfinder używa algorytmów z zakresu sztucznej inteligencji, gdyż każdy zdefiniowany w systemie pracownik ma zdefiniowane swoje cele, poglądy oraz cechy osobowościowe. Technika przemieszczania się użyta w Pathfinder (zmienna sterująca) jest wariantem w oryginalnej technice sterowania, która pozwala modelom uciekających ludzi wybierać tak cząstkowe kierunki poruszania, aby ich indywidualny czas ewakuacji był jak najkrótszy. Pathfinder zawiera również alternatywny model poruszania się tłumu bazujący na równaniach z SFPE (Engineering Guide on Human Behavior in Fire). Charakterystyka poruszania się osób składa się z dwóch części: profili i zachowań. Profile definiują prędkość poruszania się, wymiary (średnicę kołową), wygląd i kolor, natomiast zachowania określają sekwencję akcji w trakcie trwania symulacji, takich jak przejście we wskazane miejsce, postój i wyjście. Mechanizm ten jest zgodny z SFPE [39] zarówno w profilach prędkości, jak i kontroli przejścia przez drzwi. W tym trybie pracy Pathfinder odtwarza w pierwszej kolejności ręczne obliczenia, używając do tego założeń i wytycznych SFPE. Pozwala to na szybkie określenie czasu ewakuacji dla modelu budynku, a nawet dla dużych kompleksowych obiektów [40].

Wizualizację zbudowanego w programie Pathfinder modelu wykorzystanego do symulacji ewakuacji $\mathrm{z}$ budynku przedstawiono na ryc. 7 .

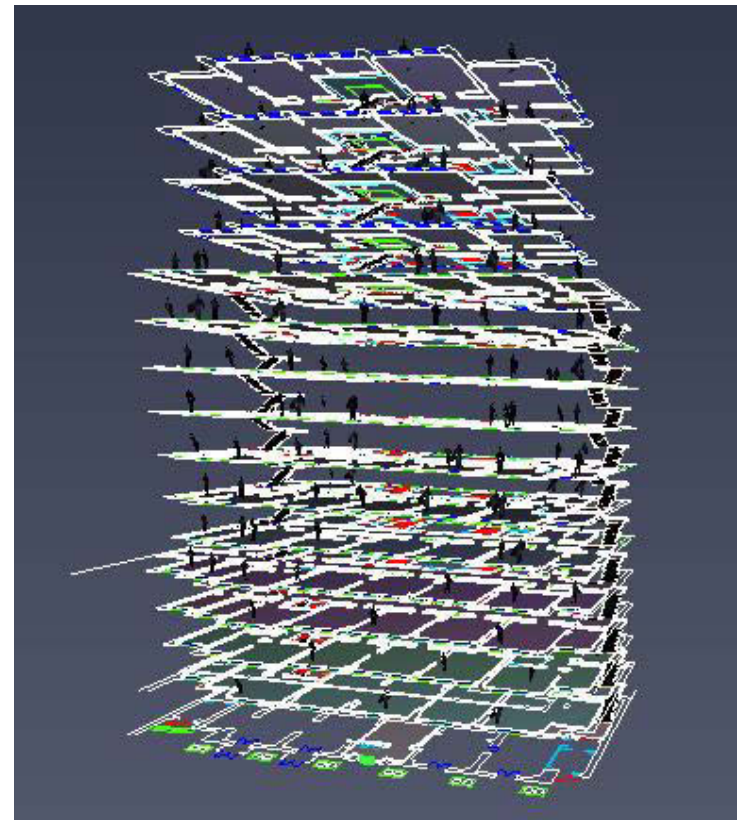

Ryc. 7. Model przedstawiający budynek wraz z rozmieszczonymi osobami w poszczególnych pomieszczeniach

Fig. 7. Model showing the building with people distributed in different rooms

Źródło: Opracowanie własne. Source: Own elaboration.

Zgodnie $\mathrm{z}$ założeniami eksperymentu w ewakuacji brało udział 137 osób, które rozmieszczono w poszczególnych pomieszczeniach budynku. Na podstawie danych literaturowych [9] oraz danych z obserwacji ewakuujących się ludzi do celów symulacji założono wartość czasu zwłoki 2 min 30 s dla każdej osoby ewakuującej się.

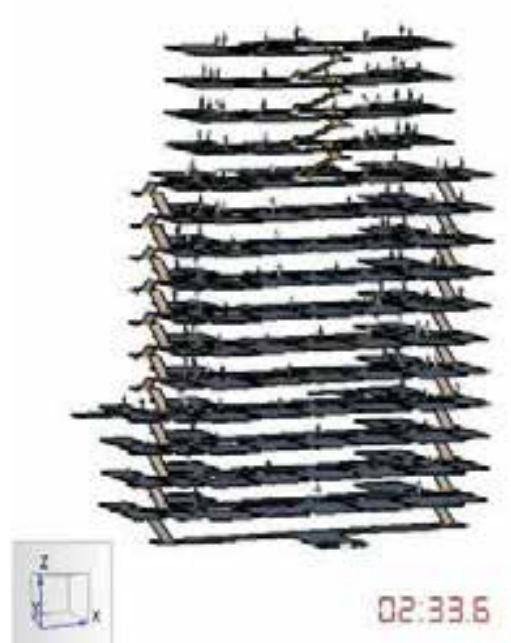

Ryc. 8. Rozpoczęcie ewakuacji po ustalonym 2,5-minutowym czasie zwłoki

Fig. 8. Begin evacuation after a set delay time of 2.5 minutes Źródło: Opracowanie własne.

Source: Own elaboration. 


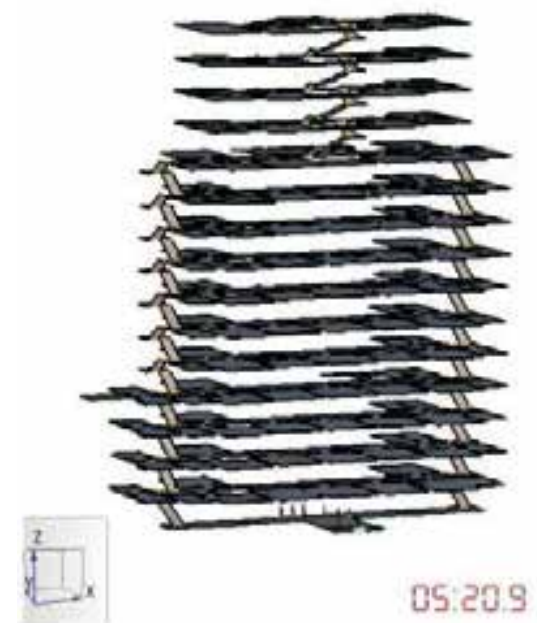

Ryc. 9. Widok po 5 minutach i 20 sekundach Fig. 9. View after 5 minutes and 20 seconds Źródło: Opracowanie własne. Source: Own elaboration.

Przeprowadzona symulacja wykazała, że zgodnie z najbardziej optymistycznym wariantem całkowity czas ewakuacji 137 osób z budynku przy założonym czasie zwłoki 2,5 minuty wyniesie 5 minut i 29,5 sekundy.

\subsection{Wyznaczenie wymaganego czasu ewakuacji na podstawie normy British Standard}

Po zastosowaniu wskazań literaturowych $[9,41]$ analiza warunków ewakuacji w oparciu o dostępny czas bezpiecznej ewakuacji i wymagany czas bezpiecznej ewakuacji przedstawia się następująco.

Na wymagany czas bezpiecznej ewakuacji (WCBE) składają się

- czas zauważenia (wykrycia),

- czas alarmu,

- czas reakcji,

- czas przemieszczania.

$$
\mathrm{WCBE}=\Delta \mathrm{t}_{\text {det }}+\Delta \mathrm{t}_{\mathrm{a}}+\left(\Delta \mathrm{t}_{\text {pre }}+\Delta \mathrm{t}_{\text {przej }}\right)
$$

gdzie:

$\mathrm{t}_{\text {det }}$ - czas detekcji, czyli czas od zainicjowania pożaru do czasu jego wykrycia przez system sygnalizacji pożarowej lub przez użytkowników

$\mathrm{t}_{\mathrm{a}}$ - czas alarmowania, czyli czas od momentu detekcji do czasu ogłoszenia alarmu

$\mathrm{t}_{\text {pre }}$ - czas wstępnych reakcji użytkowników i rozpoznania

$\mathrm{t}_{\text {przej }}$ - czas przejścia użytkowników budynku, składający się z czasu wymaganego do przejścia użytkowników do wyjścia na zabezpieczone drogi ewakuacyjne tzw. „czas przejścia” oraz czas wymaganego na przejście przez wyjścia i drogi ewakuacyjne tzw. „flow”.

W przedmiotowym obiekcie przy założeniu pożaru w jednym z pomieszczeń WCBE:
- czas zauważenia - 120 s (założono najgorszy wariant: wykrycie po $30 \mathrm{~s}$, alarm I stopnia i jego weryfikacja, następnie alarm II stopnia)

- czas alarmu - $30 \mathrm{~s}$

- czas reakcji - $90 \mathrm{~s}$

- czas przemieszczania $-280 \mathrm{~s}$

Razem WCBE $=520 \mathrm{~s}=8 \mathrm{~min} 40$ sekund

Należy zwrócić uwagę na to, że zastosowanie systemu sygnalizacji pożarowej zaalarmuje po kilkunastu sekundach od momentu powstania pożaru obsługę centrali o pożarze, a następnie obsługa sprawdzi alarm i powiadomi użytkowników przebywających w budynku o konieczności ewakuacji lub rozpocznie akcję gaśniczą, w zależności od oceny sytuacji.

\subsection{Wnioski z przeprowadzonego eksperymentu}

Porównując rzeczywisty czas ewakuacji z symulacją komputerową, czas uzyskany przy pomocy tej ostatniej jest krótszy o 3 minuty 23,5 sekundy. Trzeba jednak wziąć pod uwagę fakt, iż założenia programowe każą wybrać najkrótszą drogę ewakuującej się osobie, a w rzeczywistości ludzie z reguły wybierają drogę lepiej im znaną, tę, którą przyszli, wracają się po coś lub kogoś. Dlatego widoczna jest różnica pomiędzy uzyskanymi wynikami.

Podczas obserwacji zauważono również, że ruch nie jest ciągły tak jak w przypadku symulacji komputerowej. Różne osoby ewakuują się z różnym czasem opóźnienia, ponieważ każda jednostka zachowuje się w sposób indywidualny. Dlatego warto podczas szacowania czasów ewakuacji zakładać margines bezpieczeństwa, aby mieć pewność, że ludzie ewakuują się w bezpiecznych warunkach.

Jednocześnie warto zwrócić uwagę na wykonane obliczenia w oparciu o wytyczne standardów [9], które praktycznie przy założeniu najmniej korzystnego wariantu pokrywają się z wynikami obserwowanej ewakuacji.

W trakcie trwania eksperymentu można było zaobserwować widoczne cztery fazy modelu koncepcyjnego.

\section{Podsumowanie}

W celu poznania rzeczywistych zachowań użytkowników podczas ewakuacji należy dokonywać szczegółowych analiz rzeczywistych zdarzeń, aby poznać które działania prowadzą do opóźnień i jakie zachowania mają decydujący wpływ na przebieg ewakuacji. Następnie teorię zachowań należy przetłumaczyć na język programowania. Obecne modele nadal są niekompletne i uproszczone, nie stanowią odzwierciedlenia rzeczywistego zachowania użytkowników podczas pożarów budynków. Rozwiązaniem tego problemu jest tworzenie kompleksowej, solidnej teorii na temat zachowania ludzi podczas ewakuacji w trakcie pożaru budynku.

Każdy proces ewakuacji zaczyna się nowymi wskazówkami i informacjami z otoczenia fizycznego i społecznego. Po pierwsze sygnały trzeba dostrzegać, interpretować, a następnie należy podjąć decyzję, co należy zrobić dalej. Podczas ewakuacji osób proces ten należy powtó- 
rzyć kilka razy, angażując się w różnorodne działania zarówno przed, jak i w trakcie ruchu celowego ewakuacji [4].

Studium przypadków z prób ewakuacji, pożarów i katastrof powinno być włączone do aktualizacji obecnych modeli ewakuacji, aby możliwe było dokładne odzwierciedlenie zachowania użytkowników podczas ewakuacji. Dzięki poznaniu zachowań ludzkich możliwe będzie tworzenie dokładnych i realistycznych modeli ewakuacji, które przekładać się będą na zapewnienie bezpieczeństwa użytkownikom budynków.

\section{Literatura}

1. Kuk M.L., A Nightclub, A Fire ... And a Generation Vanishes. The Story of the Rhythm Night Club Tragedy, "Firehouse" Vol. 35 Issue 11, 2010, pp. 96-100.

2. http://www.usfa.dhs.gov/statistics/national/index.shtm USFA. 2007

3. Hall J. R., How Many People Can Be Saved from Home Fires if Given More Time to Escape?, "Fire Technology" Vol.40 Issue 2, 2004, pp. 117-126.

4. Kuligowski E.D., Modeling Human Behavior during Building Fires, NIST Technical Note 1619, 2008.

5. Purser D.A., Bensilum M., Quantification of behavior for engineering design standards and escape time calculations, "Safety Science" Vol. 38, 2001.

6. Pires T.T., An approach for modeling human cognitive behavior In evacuation models, "Fire Safety Journal" Vol. 40, 2005.

7. Rubadiri L., Ndumu D.T., Roberts J.P., Predicting the evacuation capability of mobility-impaired occupants, "Fire Technology" Vol. 33, 1997.

8. Kobes M., Helsloot I., de Vries B., Post J.G., Building safety and human behavior in fire: A literature review, "Fire Safety Journal" Vol. 45, 2010.

9. PD 7974-6: 2004 The application of fire safety engineering principles to fire safety design of buildings. Part 6: Human factors. Life safety strategies. Occupant evacuation, behavior and condition.

10. Hankin B.D., Wright R.A., Passenger flow in subways, "Operational Research Quarterly" Vol. 9 Issue 2, 1958.

11. Hoel L.A. Traffic and Highway Engineering, Cengage Learning, 1968.

12. Mayne A.J., Some further results in the theory of pedestrians and road traffic, "Biometrika", Vol. 41, 1954.

13. O'Flaherty C.A. and Parkinson M.H., Movement on a city centre footway, "Traffic engineering and control" Vol. 10, 1972, pp. 160-163.

14. National Fire Protection Association Fire Protection Handbook - 2003.

15. Hamacher H.W. and Tjandra S.A., Mathematical modelling of evacuation problems: A state of art., "Berichte des Fraunhofer", ITWM, Issue 24, 2001.

16. Yuhaski S.J., MacGregor Smith J., Modeling circulation systems in buildings using state dependent queueing models, "Queueing System" Vol. 4, 1989.

17. Garbrecht D., Describing pedestrian and car trips by transition matrices, "Traffic Quarterly" Vol. 27, 1973.

18. Henderson L.F., The statistics of crowd fluids, "Nature" Vol. 229, 1971.

19. Henderson L.F., Jenkins D.M.., Response of pedestrians to traffic challenge, "Transportation Research" Vol. 8, 1973.

20. Henderson L.F., Lyons D.J., Sexual differences in human crowd motion, "Nature" Vol. 240, 1972.

21. Encyklopedia $P W N$, [dok. elektr.] http://encyklopedia.pwn. $\mathrm{pl} /$ lista.php? $\mathrm{co}=\mathrm{t} \% \mathrm{~B} 3 \mathrm{um}$
22. Blumer H., Collective Behavior, Irvington Publishers, 1951.

23. http://pl.wikipedia.org/wiki/Tłum dnia 12.12.2010 r.

24. Park R.E., On Social Control and Collective Behavior, University of Chicago Press, 1967.

25. Le Bon G., Psychologia thumu, Wydawnictwo Marek Derewiecki, 2007.

26. Spearpoint M., Effect of Pre-evacuation Distributions on Evacuation Times in the Simulex Model, "Journal of Fire Protection Engineering”, Vol. 14, 2004, pp. 33-54.

27. Thompson P.A., Wu J., Marchant E.W., Modelling Evacuation in Multi-storey Buildings with Simulex, "Fire Engineering" Vol. 56, 1996, pp.7-11.

28. Fahy R.F., EXIT89 High-rise Evacuation Model - Recent Enhancements and Example Applications" s. 1001-1005 in Interflam '96, International Interflam Conference - 7th Proceedings, edited by C. A. Franks and S. Grayson. London, England: Interscience Communications Ltd. 1996.

29. Bensilum M., Purser D.A., Gridflow: An object-oriented building evacuation model combining pre-movement and movement behaviours for performance-based design" In 7th International Symposium on Fire Safety Science, edited by D. Evans. London, England: Interscience Communications Ltd. 2002.

30. Fraser-Mitchell J.N., Modelling Human Behavior within the Fire Risk Assessment Tool "CRISP", "Fire and Materials" Vol. 23, 1999, pp. 349-355.

31. Filippidis L., Galea E., Gwynne S., Lawrence. P., Representing the Influence of Signage on Evacuation Behaviour within an Evacuation Model, "Journal of Fire Protection Engineering" Vol. 16, 2006, pp. 37-73.

32. Gwynne S., Galea E.R., Lawrence P.J., Owen M., Filippidis L., Adaptive Decision-Making in building EXODUS, "Journal of Applied Fire Science" Vol. 8, 1999, pp. 265-289.

33. Brennan P., Modelling Cue Recognition and Pre-Evacuation Response, w: Proceedings -6 International Symposium of Fire Safety Science, International Association for Fire Safety Science, London, England, 1999, 1029-1040.

34. Canter D., Breaux J., Sime J., Domestic, Multiple Occupancy and Hospital Fires, w: Fires and Human Behaviour, David Canter (red.), New York, NY: John Wiley \& Sons. 1980, 117-136.

35. Starbuck W.H., Milliken F.J., 'Executives' perceptual filters: What they notice and how they make sense, $\mathrm{w}$ : The executive effect: Concepts and methods for studying top managers, D. C. Hambrick (red), Greenwich, CT: JAI, 1988, 35-65.

36. Canter D., Donald I., Chalk J., Pedestrian Behaviour during Emergencies Underground: The psychology of crowd control under life threatening circumstances, in Safety in Road and Rail Tunnels, A. Vardy (red.), Bedford: Independent Technical Conferences Ltd, 1992, 135-150.

37. Turner R.H., Killian L.M., Collective Behavior, Englewood Cliffs, NJ: Prentice Hall, Inc. 1987.

38. Connell R., Collective Behavior in the September 11, 2001 Evacuation of the World Trade Center, "Preliminary Paper \#313", Newark: DE: University of Delaware Disaster Research Center, 2001.

39. SFPE Handbook of Fire Protection Engineering-Third Edition (2002).

40. http://www.pyrosim.pl/pathfinder-symulacja-ewakuacji-z-budynku/budownictwo-ogrzewnictwo.html dnia 10.08.2013r

41. Cłapa I., Porowski R., Dziubiński M., Wybrane modele obliczeniowe czasów ewakuacji, BiTP Vol. 24 Issue 4, 2011, pp. 71-79. 
prof. dr hab. inż. Marek Dziubiński, pracownik naukowy Politechniki Łódzkiej, pełni obecnie funkcję kierownika Katedry Inżynierii Chemicznej na Wydziale Inżynierii Procesowej i Ochrony Środowiska Politechniki Łódzkiej. Zainteresowania naukowe to przepływy wielofazowe ze szczególnym uwzględnieniem przepływów dwufazowych ciecz-gaz cieczy newtonowskich i nienewtonowskich, reologia i reometria techniczna, elementy ryzyka i bezpieczeństwa procesowego (wypływy jednoi dwufazowe z rurociągów i zbiorników) oraz utrzymywanie emulsji oraz ich właściwości. mgr inż. Iwona Clapa, absolwentka Wydziału Inżynierii Bezpieczeństwa Pożarowego Szkoły Głównej Służby Pożarniczej w Warszawie. Obecnie doktorantka na Wydziale Inżynierii Procesowej i Ochrony Środowiska SGSP. Obszar zainteresowań naukowych to modelowanie numeryczne procesów ewakuacji oraz inżynieria bezpieczeństwa pożarowego. 